Кораев Г. Т. Обретая биографическое тело : рецензия на книгу А. В. Коровашко о М. М. Бахтине // Философия. Журнал Высшей школы экономики. - 2017. - Т. I, № 3. C. $175^{-182}$.

\title{
ГEPMAH KOPAEB*
}

\section{ОВРЕТАЯ ВИОГРАФИЧЕСКОЕ ТЕЛО**}

\author{
РЕЦЕНЗИЯ НА КНИГУ А.В. КОРОВАШКО О М. М. БАХТИНЕ
}

КОРОВАШКО А. В. МИХАИЛ БАХТИН. - М. : МОЛОААЯ ГВАРАИЯ, 2017. - (ЖИЗНЬ ЗАМЕЧАТЕАЬНЫХ АЮАЕЙ ; 1852/1652)

Вышедшая в 2017 году в серии «Жизнь замечательных людей» биография М. М. Бахтина, написанная Алексеем Коровашко, является одной из первых биографий Бахтина на русском языке. Эта книга появилась в ситуации не самой высокой конкуренции. С одной стороны, классическая биография, написанная К. Кларк и М. Холквистом еще в 1984 г. (Clark, Holquist, 1984), до сих пор не переведена. С другой стороны, русскую биографию, и не одну, учитывая дикую популярность Бахтина на родине, было бы логично ожидать уже как минимум с начала 80-х. Однако на данный момент имеется не так много. Нужно упомянуть работы монографического и биографического толка таких авторов, как В. М. Алпатов, Л. С. и С. С. Конкины, В. Л. Махлин, Н. А. Паньков, И. Л. Попова. Но, несмотря на высокий профессионализм этих работ, новая биография Бахтина все же ожидалась как необходимая. Необходимость здесь равна задаче по созданию целостного образа Бахтина как учёного и человека. И книга Коровашко призвана решить эту задачу. Ведь отсутствие целостного образа мыслителя создает немалые герменевтические проблемы на подступах к его идеям и интуициям. Особую значимость эта задача приобретает по отношению к русской философской традиции, почти оборвавшейся и, вне всякого сомнения, кардинально изменившейся после 1917 г.

В случае с Бахтиным дело осложняется еще и засильем загадок и мистификаций, как сложившихся до, так и появившихся после его смерти, непременно сопровождающих речь о его жизненном и творческом пути. Одной из целей рассматриваемой книги, пусть и не проговариваемой

* Кораев Герман Таймуразович, аспирант Института гуманитарных наук Балтийского федерального университета им. И. Канта (Калининград), germankoraev@gmail.com.

** (C) Кораев, Г. Т. ( ) Философия. Журнал Высшей школы экономики. 
открыто, но и не скрываемой, является именно демистификация и демифологизация дискурса о Бахтине. Возможно, с этим связан стиль изложения, избранный Коровашко, поначалу даже шокирующий интенсивностью своей иронически-цинической составляющей. Стиль этот, по-видимому, избран автором, чтобы уйти от реверансов и придыханий, ставших непреходящей частью письма множества бахтинистов. Ирония здесь выполняет свою прямую функцию-дистаниирует речь о герое от общепринятых оценок, сохраняя возможность вполне объективного описания. Хотя нельзя не отметить, что подчас иронический метод Коровашко дает сбои, раз за разом порождая высказывания, состоящие из неприкрытой агрессии по отношению к героям книги - как к людям, так и к идеям.

Несмотря на очевидные недостатки избранного стиля, книга Коровашко все же представляет собой именно целъную биографию, из которой читатель может получить вполне исчерпывающее представление о трудах и днях Михаила Бахтина. Для достижения этой цели автор обращается к множеству интереснейших материалов. Например, он восстанавливает юношеский период жизни Бахтина, рассматривая его сквозь призму деятельности кружка, в который входил его старший брат Н. М. Бахтин, а также Л. В. Пумпянский, М. И. Лопатто и другие. С опорой на воспоминания Лопатто создается объемная картина деятельности кружка, переродившегося впоследствии в кружок под названием «омфалос». Главным родом занятий кружка стало пародирование творчества современных ему писателей и поэтов от Ахматовой до Брюсова.

Немало места в книге уделено дискуссии об образовании Бахтина. Рассматривая различные существующие версии,- только сам Бахтин оставил не менее четырех вариантов своей учебной биографии, - автор приходит к следующему выводу: Бахтин не только не учился в университете, но даже не закончил гимназии. Эта курьезная деталь биографии затем сопровождает множество эпизодов академической карьеры Бахтина, подчас придавая ей авантюрный оттенок ${ }^{1}$.

Интересно освещен также и саранский период жизни Бахтина. Бахтин с женой, переехавшие туда вскоре после окончания Великой Отечествен-

\footnotetext{
1 Занимательна, хоть и не соответствует действительности, автобиография, которую Бахтин подал в Витебский институт народного образования в 1920 г. Согласно ей, Бахтин, никогда не бывавший за границей, учился в Марбурге и Берлине (подразумевается, видимо, учеба у Г. Когена и П. Наторпа), а затем 3 года работал на кафедре Ф. Ф. Зелинского (Коровашко, 2017: 109-110).
} 
ной войны, были поселены в здание бывшей городской тюрьмы². Бахтин, приглашенный на должность доцента кафедры всеобщей литературы Мордовского государственного педагогического института, через два года работы становится заведующим кафедрой и работает там до выхода на пенсию в 1961 г. Воспоминания коллеги Бахтина по кафедре В. Б. Естифеевой и выпускника местного вуза Е. И. Лаврова, обильно цитируемые в книге, дают показательный срез бахтинского пребывания в Саранске. В воспоминаниях образ Бахтина-ученого дополняется образом Бахтина-преподавателя. Он поражал своих саранских слушателей «глубиной мысли, огромной эрудицией, эмоциональностью речи» (Коровашко, 2017: 410). Также в воспоминаниях Естифеевой присутствуют бытовые и комические зарисовки из университетской жизни. $\mathrm{K}$ примеру, на одном из заседаний коллега-филолог всерьез спрашивал у Бахтина: «Михаил Михайлович, кто такой Фрейд?» (там же: 403). В дополнение к воспоминаниям коллег и выпускников даны протоколы комиссии, проверявшей деятельность кафедры Бахтина весной 1951 г. Но и здесь - правда, уже канцелярским языком-Бахтин характеризуется как вполне эрудированный и свободно владеющий своим материалом лектор. В итоге Бахтин, обыкновенно представленный раздробленным на варианты Бахтина и в плане творчества, и в плане жизни, в книге Коровашко обретает свое полноценное биографическое тело.

Если - за исключением стиля - биографическая составляющая работы выполнена превосходно, то с теоретической частью книги дела обстоят не так хорошо. Проблема тут связана, не в последнюю очередь, с философской спецификой творческого наследия Бахтина. Коровашко в целом справляется с литературоведческим материалом, но на философских работах Бахтина становится заметна пробуксовка. И хотя понятно, что сам формат книги-жизнеописания никак не рассчитан на пристальное рассмотрение сложных концептуальных вопросов, затронутых Бахтиным в его философских трудах, уровень их анализа все же мог быть и выше.

Метод, избранный автором для анализа и подачи читателю философского материала, можно охарактеризовать как полностью экстерналистский, то есть никак не касающийся самой философии. Для разъяснения действительно сложных бахтинских концептов автор либо начинает «копать» этимологию, либо щедро вынимает из рукава припасенные

${ }^{2}$ Бахтин вспоминал: «У нас с Еленой Александровной была вполне комфортабельная камера...» (Коровашко, 2017: 401). 
аналогии бахтинских ходов мысли. Аналогии эти-адекватные, по мнению автора,- он находит в трудах не только философов, но также ученых и поэтов. Такой филологический метод, несомненно, обоснован и даже необходим, однако недостаточен. Все-таки философия - это рефлексивная деятельность, это работа с понятиями. А понятия не равны словам: понятия крепко связаны самой необходимостью мысли, сосуществуя в единстве выражаемого ими смысла. K тому же, нередко аналогии Коровашко просто не попадают в цель. Я ограничусь несколькими примерами.

На странице 131 Коровашко в попытках достичь ясности в понимании бахтинской категории поступка приводит цитату, в которой говорится про рискованность как одну из его существенных черт. Дальше он пишет: «Возникает даже соблазн [курсив мой. - Г. K.] соотнести бахтинскую категорию поступка с гегелевской концепцией „раба“ и „господина“»,- и после цитаты из лекций А. Кожева о Гегеле заключает: «Поступок [курсив мой. - Г. K.] начинается там, где в дело вступает Господин, и заканчивается там, где застыл в своем природном состоянии Раб» (Коровашко, 2017: 131). Этим пассажем параграф заканчивается, а читателю только и остается, что недоуменно искать результат соотнесения категории Бахтина с концепцией Гегеля-соотнесения, соблазн прибегнуть к которому автор, к сожалению, преодолеть так и не смог.

Рассмотрев категорию поступка, Коровашко переходит к бахтинскому понятию ответственности. В жажде «разобраться с оттенками значения» этого понятия он начинает с цитаты: «Ответственность поступка - есть учет в нем всех факторов: и смысловой значимости, и фактического свершения во всей его конкретной историчности и индивидуальности...» (там же: 135). Заметив, что бахтинские разъяснения вряд ли можно признать исчерпывающими, автор решается «транскрибировать» содержание приведенного им текста. У него получается следующее: «Ответственность поступка, как ее понимает Бахтин,- - это учет всех тех последствий, к которым он способен привести...» (там же). В приведенной цитате Бахтин указывает на то, что через ответственность мир, расколотый на две половины - смысловую и фактическую - нашими неверными мыслительными установками, снова стягивается в единое целое. Вряд ли кому-либо удастся понять, как можно «дотранскрибировать» эту мысль до учета возможных последствий поступка. Но этим дело не кончается. Автор пишет: «Чтобы предложенное нами толкование не показалось чересчур приземленным [sic!], свяжем его 
с концепцией Вызова и Ответа (challenge and response) [...]. Стоит подставить в этой схеме [Вызова и Ответа. - Г. К.] вместо цивилизации отдельно взятого человека, как мы получаем рецепт моделирования поступка, взятого именно в бахтинском смысле» (Коровашко, 2017: 136). Здесь, я думаю, комментарии будут излишни.

Добравшись до понятия «участное мышление», Коровашко заявляет, что «,участное мышление“ вызывает безусловные ассоциации [sic!] с понятием „экологической валидности“» (там же: 141). «Экологическая валидность»- способ установления научности текста, имеющий ряд критериев, таких как способность трансформировать общество в целом, сказать что-то важное, что не сводится к тривиальным суждениям, но говорить при этом на понятном людям языке. Оставим в стороне вопрос вменяемости таких критериев и уж тем более их релевантности по отношению к философии. Лучше заслушаем приговор, который автор выносит работе Бахтина: «Если говорить откровенно, то трактат Бахтина „К философии поступка“ перечисленным требованиям удовлетворяет далеко не полностью» (там же). И дальше: Если отодвинуть терминологическую завесу, - пишет Коровашко, - созданную Бахтиным, примеряющим роль солидного философа немецкого образца (в двадцать с небольшим лет это простительно), то замысел его трактата приобретает более зримые формы» (там же: 143). Невооруженным взглядом видны муки, доставляемые Коровашко ненавистной ему терминологией. Он, видимо, предполагает, что если «отжать „воду“ из творожистой массы бахтинских медитаций, обильно уснащенных неокантианской фразеологией и россыпями самодовольного творчества» (там же: 142), то текст сразу станет ясным и прозрачным, и ему останется только провести его стилистический анализ,- большая ли беда, что за скобками окажется смысл.

Отзвуки все той же проблемы слышны в месте, казалось бы, совсем неожиданном, где автор рассматривает вопрос о принадлежности Бахтину статьи «Современный витализм» и где речь о самой философии и не заходит (там же: 220-222) - но именно в этом, как я покажу далее, и скрывается проблема. Если кратко резюмировать «факты», вызывающие сомнения А. Коровашко в авторстве Бахтина, получится следующее: (1) С.Г. Бочаров заявляет о существовании фотокопии журнального оттиска статьи, на которой рукой Канаева письменно утверждается единоличное авторство Бахтина. Но так как данная фотокопия не обнародована, то нет и окончательной уверенности в авторстве. (2) Тематика статьи о витализме лежит в области научных интересов 
Канаева и находится вне таковых Бахтина. Написание этой статьи потребовало бы от Бахтина «солидной начитанности в тогдашней литературе по теоретической и экспериментальной биологии», а также «ощущения личной причастности к столкновениям конкурирующих естественно-научных парадигм». Но автор не понимает, откуда эти качества могли взяться у Бахтина. (3) Почему, спрашивает Коровашко, Бахтин, раз он был такой «многостаночник», не опубликовал работу, к примеру, по египтологии или ассириологии?

С замечанием из первого пункта нельзя не согласиться. Если фотокопии будут опубликованы, вопрос об авторстве будет снят. Полемические предположения третьего пункта не нуждаются в рассмотрении, на мой взгляд, так как к делу не относятся. По существу остается разобрать лишь второй пункт. По сути Коровашко считает возможным ставить под сомнение атрибуцию «Современного витализма» Бахтину, основываясь на том факте, что Бахтин не был специалистом по биологии. А раз он не был биологом, то, соответственно, по мнению Коровашко, неоткуда взяться у Бахтина знаниям о витализме, да и интересу к нему.

На это я хотел бы возразить следующее. Во-первых, когда мы говорим о витализме и, в частности, о Г. Дрише,- именно разбору философской части его учения (критике механицизма и понятию энтелехии) посвящена большая часть «Современного витализма»,- нельзя забывать, что Дриш непосредственно увязывал витализм с фундаментальной философской проблематикой. Таким же образом на витализм смотрели и другие философы-как современники, так и представители последующих поколений (например, Х. Плеснер и М. Хайдеггер).

Во-вторых, «Современный витализм»-это статья не по биологии, а $о$ биологии, написанная в рамках философии биологии. Неслучайно в ее начале имеется введение, в котором содержится не только краткая история витализма как особого направления в истолковании природы, но и философско-методологическая часть, в которой ставится вопрос о методе в науке вообще и в биологии в частности. В-третьих, на каком основании утверждается необходимость серьезных познаний в теоретической и экспериментальной биологии для написания этой статьи? Открыв статью, мы увидим больше ссылок на известных философов, касавшихся проблем жизни. Кроме Дриша, в статье упоминаются Аристотель, Э. Гартман и А. Бергсон. Что касается вопросов о сущности жизни и ее смысле, то у философа живую реакцию и ощущение личной причастности они не вызывать не могут. Интерес Бахтина и членов 
его круга к работам Дриша и проблематике, им затрагиваемой, можно подтвердить прямыми ссылками на него в работе «По ту сторону социального», вышедшей в 1925 г., то есть за год до «Современного витализма», а также неоднократными упоминаниями Дриша в книге «Фрейдизм. Критический очерк».

Последний, хотя и не по значению, факт, на который хотелось бы указать, - это существование книги известнейшего русского философа Н. О. Лосского, который за четыре года до обсуждаемой статьи опубликовал целую книгу о витализме. Книга эта, что интересно, имеет то же название, что и статья Бахтина (Лосский, 1922). Также схожи в книге и в статье исследуемый материал и принципы его изложения, но сравнительный анализ их здесь проводить не место. Остается только сказать, что аргументы Коровашко против приписывания авторства «Современного витализма» Бахтину критики не выдерживают. А все указанные проблемы и недостатки происходят из-за философской недостаточности автора.

Подведем итоги: в композиционном и смысловом плане законченная биографическая составляющая книги интересна и нареканий не вызывает. Теоретическая же часть страдает рядом недостатков, главный из которых - слабость проводимого в ней анализа философских трудов и идей Бахтина. Поэтому нужно обязательно читать эту биографию Михаила Бахтина - но только с тем условием, что суждения о его творчестве ею одной не ограничатся.

\section{ЛИТЕРАТУРА}

Коровашко А. В. Михаил Бахтин. - М. : Молодая гвардия, 2017. - (Жизнь замечательных людей ; 1852/1652).

Лосский Н. О. Современный витализм. - Петроград : Кооп. изд-во литераторов и ученых, 1922.

Clark K., Holquist M. Mikhail Bakhtin. - Cambridge (Mass.), London : Belknap Press of Harvard Univ. Press, 1984. 
Korayev, G. T. 2017. "Obretaya biograficheskoye telo [Acquiring Biographical Body]: retsenziya na knigu A. V. Korovashko o M. M. Bakhtine [A Review of the Book on M. M. Bakhtin by A. V. Korovashko]" [in Russian]. Filosofiya. Zhurnal Vysshey shkoly ekonomiki [Philosophy. Journal of the Higher School of Economics] I (3), 175-182.

\section{German Korayev}

PhD STUdent at the Institute For the Humanities, Immanuel Kant Baltic Federal University, Kaliningrad

\section{ACQUIRING BIOGRAPHICAL BODY}

\section{A Review of the Book on M. M. Bakhtin by A. V. Korovashko}

KorovashKo, A. V. 2017. Mikhail BaKhtin [Mikhail BaKhtin] [in Russian]. Zhizn' ZAMECHATEL'NYKH LYUDEY [LIVES OF REMARKABLE PEOPLE], 1852/1652. MOSKVA [MOSCOW]: MOLODAYA GVARDIYA

REFERENCES

Clark, K., and M. Holquist. 1984. Mikhail Bakhtin. Cambridge (Mass.) and London: Belknap Press of Harvard Univ. Press.

Korovashko, A. V. 2017. Mikhail Bakhtin [Mikhail Bakhtin] [in Russian]. Zhizn' zamechatel'nykh lyudey [Lives of Remarkable People], 1852/1652. Moskva [Moscow]: Molodaya gvardiya.

Losskiy, N. O. 1922. Sovremennyy vitalizm [Contemporary Vitalism] [in Russian]. Petrograd: Koop. izd-vo literatorov i uchenykh. 